\title{
PERAN DAN INOVASI REMAJA MASJID DALAM MEMBUAT PROGRAM DAKWAH MODERN DI MASJID AGUNG JAWA TENGAH
}

\author{
Hery Pamungkas \\ Universitas Dian Nuswantoro \\ heripamungkas170@gmail.com
}

Received: November 19, 2020; Revised: January 13, 2021; Accepted: February 20, 2021

\begin{abstract}
Abstrak
Fungsi masjid tidak hanya sebagai tempat ibadah namun juga center of excellent pembangunan umat melalui konsep pendidikan dakwah modern yang diterima dengan baik oleh masyarakat. Permasalahan penelitian ini adalah bagaimana seharusnya pengurus masjid melibatkan remaja masjid sebagai bagian dari pengembangan dakwah modern. Tujuan penelitian ini adalah untuk melihat bentuk partisipasi dan keterlibatan remaja masjid di Masjid Agung Jawa Tengah dalam membuat inovasi program dakwah modern melalui sentuhan broadcasting. Teori yang digunakan adalah teori difusi inovasi. Penelitian ini menggunakan pendekatan kualitatif dengan metode studi kasus. Proses pengumpulan data di lakukan dengan observasi dan wawancara dengan para remaja masjid yang menjadi bagian dari crew MAJT TV. Hasil penelitian menunjukkan bahwa partisipasi remaja masjid dalam proses difusi inovasi pengembangan model dakwah modern di Masjid Agung Jawa Tengah mampu menunjukkan hasil efektif dalam upaya pengembangan dakwah konvensional menjadi dakwah digital. Ruang usulan dari remaja masjid kepada pengurus masjid dalam konteks pengembangan konten masih menjadi persoalan. Hasil penelitian ini diharapkan dapat menjadi dasar pengembangan penelitian mengenai pengembangan model dakwah modern melalui kemitraan dakwah dalam sudut pandang pemberdayaan.
\end{abstract}

\section{Kata Kunci: Inovasi Dakwah, Manajemen Penyiaran, Pemberdayaan, Remaja Masjid MAJT}

\begin{abstract}
The function of a mosque should not only be a place for fostering ritual worship but as a center of excellence in community development through the concept of modern da'wah education which is well accepted by the community. The problem of this research is how mosque administrators should involve mosque youth as part of the development of what modern da'wah looks like. This study seeks to find out how the participation and involvement of young mosques in the Grand Mosque of Central Java as research subjects in making innovations in modern da'wah programs through broadcasting touches. By using a review in the diffusion theory of innovation, that the innovation of successful innovation in an educational da'wah program in the community cannot only be carried out
\end{abstract}


unilaterally or by an institution alone, but there must be involvement of many parties, one of which is the mosque youth. This research method uses a qualitative approach with a case study strategy of how to manage the content of the dakwah program through the process of collecting data in the field through observation techniques and conducting interviews with mosque youth who are part of the MAJT TV crew. The results of this study indicate that the participation of young mosques in the process of diffusion of innovation in the development of modern dakwah models at the Great Mosque of Central Java is able to show effective results in becoming a new way of developing digital ulama da'wah which has been broadcasting or the way of preaching that has been carried out tends to seem conventional. The lack of space for proposals from mosque youths to mosque administrators in the context of content development is still a problem. This study is very important because there is still a lack of research on communication and empowerment of mosque youth by mosque administrators in the field of developing modern dakwah models through da'wah partnerships so far, so it is hoped that it can become a reference for further research, especially in the field of communication and empowerment.

\section{Keywords: Broadcasting Management, Da'wah innovation, Empowerment,} MAJT, Mosque youth

\section{Pendahuluan}

Masjid merupakan sekolah sekaligus laboratorium praktikum nilai-nilai pendidikan yang universal. Seiring waktu berjalan, terjadi pergeseran fungsi strategis edukatif pada masjid dimana masjid lebih difungsikan dari aspek sakralnya dan mengabaikan fungs dan sosialnya. Ironisnya, para pengurus masjid justru hanya sekedar berlomba memperindah kemegahan bangunan masjid dan melupakan esensi dari fungsi masjid sebagai laboratorium pendidikan yang semestinya. Perlu adanya kesadaran umat untuk bersemangat meramaikan dan menjadikan masjid sebagai center of excellent pembangunan umat melalui konsep pendidikan dakwah modern yang diterima dengan baik oleh masyarakat.

Masjid berperan signifikan
dalam mengembangkan dan
membangun kapabilitas intelektual

umat, kegiatan sosial kemasyarakatan, dan menjadi ruang diskusi untuk mencari solusi permasalahan umat terkini. Masjid Agung Jawa Tengah, masjid terbesar di Indonesia bahkan Asia Tenggara menjadi pusat kegiatan ibadah muslim sekaligus pusat peradaban yang menjadi kebanggaan umat muslim khususnya di Kota Semarang Jawa Tengah. Masjid yang berlokasi di jl. Gajah Raya, Kelurahan Sambirejo, Kecamatan Gayamsari, Kota Semarang Jawa Tengah luas bangunan $7.699 \mathrm{~m} 2$ ini memiliki daya tampung sebanyak lima belas ribu jamaah.

Dikutip dari www.krjogja.com, berbagai kerja sama internasional aktif dilakukan Masjid Agung Jawa Tengah atau MAJT untuk terus menjadi pusat pengembangan keilmuan Islam Nusantara ala Indonesia dan kini menjadi pusat rujukan studi banding 
negara-negara Asia, Eropa, Amerika dan Timur Tengah. Kawasan masjid inipun sedang disiapkan menjadi pusat pendidikan, kesehatan dan perdagangan termasuk disiapkan pembangunan Rumah Sakit bertaraf internasional seluas 10 hektar, perguruan tinggi, hingga pusat bisnis termasuk menjadikan kawasan Masjid Agung Jawa Tengah sebagai 'Little Mekkah'.

Dalam perkembangannya, pengelola Masjid Agung Jawa Tengah merasa perlu memiliki sebuah unit bisnis dalam hal ini media penyiaran elektronik yang di pandang mampu ikut memberikan kontribusi dalam ikut mensiarkan berbagai agenda kegiatan dakwah masjid agar dapat tersosialisasikan dengan baik di masyarakat. Bekerjasama dengan Universitas Dian Nuswantoro sebagai salah satu perguruan tinggi swasta di Kota Semarang bersama dengan TVKU Semarang yang merupakan salah satu lembaga penyiaran televisi lokal di Jawa Tengah yang lahir atau dimiliki oleh kampus Udinus, akhirnya Masjid Agung Jawa Tengah berhasil memiliki sebuah media kanal dakwah yang dikenal dengan Masjid Agung Jawa Tengah TV atau MAJT TV yang diresmikan pada tanggal 14 februari 2018 yang diharapkan menjadi media modern yang menjembatani programprogram dakwah Masjid Agung Jawa Tengah agar bisa dinikmati oleh masyarakat luas.

Namun demikian, menjadi sebuah persoalan ketika pengelolaan MAJT TV memerlukan penanganan yang serius terlebih sebagai bagian media promosi yang juga merupakan unit usaha dari masjid yang perlu dioptimalisasikan fungsi manajerialnya dalam menunjang komunikasi media yang efektif kepada masyarakat termasuk keinginan selain berfungsi sebagai media broadcast kegiatan masjid. Dalam pembangunannya, diperlukan kerjasama yang baik antar pihak terkait dan kolaborasi dengan bagian atau unit bisnis yang lain untuk mencapai sebuah tujuan yang telah disepakati bersama.

Berdasar hasil observasi peneliti, terdapat tiga orang remaja masjid dengan latar belakang status mahasiswa yang setiap harinya menggawangi siaran MAJT TV.

Keberhasilan inovasi sebuah program dakwah yang edukatif di masyarakat tidak bisa dilakukan secara sepihak oleh sebuah lembaga atau media saja maupun pemerintah daerah semata. Diperlukan sinergi antara pengelola masjid, pemerintah, pengelola media, dan masyarakat. Hal ini sejalan dengan paradigma Good Governance yang mengedepankan keterpaduan antara Masjid sebagai pusat kegiatan keIslaman, pemerintah sebagai negara, media massa sebagai pihak swasta, dan masyarakat sebagai konsumennya.

Teori Difusi Inovasi pada
dasarnya menjelaskan proses
bagaimana suatu inovasi
disampaikan (dikomunikasikan)
melalui saluran-saluran tertentu
sepanjang waktu kepada sekelompok
anggota dari sistem sosial. Hal
tersebut sejalan dengan pengertian
difusi dari Rogers (1961), yaitu "as
the process by which an innovation
is communicated through certain
channels over time among the
members of a social system." Salah


satu definisi difusi inovasi dalam taraf perkembangan ini antara lain dikemukakan Parker (1974), yang mendefinisikan difusi sebagai suatu proses yang berperan memberi nilai tambah pada fungsi produksi atau proses ekonomi. Dia juga menyebutkan bahwa difusi merupakan suatu tahapan dalam proses perubahan teknik (technical change).

Difusi merupakan suatu tahapan dimana keuntungan dari suatu inovasi berlaku umum. Dari inovator, inovasi diteruskan melalui pengguna lain hingga akhirnya menjadi hal yang biasa dan diterima sebagai bagian dari kegiatan produktif. Inovasi dalam dakwah sangat berperan penting dalam menciptakan penerimaan yang lebih efektif dalam memahami isi atau konten dakwah yang disampaikan. Dalam literatur penelitian sebelumnya disebutkan, bahwa dalam menyampaikan ajaran Islam, dakwah dapat menggunakan berbagai wasilah. Hamzah Ya'qub membagi wasilah dakwah menjadi lima macam, yaitu: Lisan, Tulisan, Lukisan, Audio visual, dan Akhlak (Aziz, 2004: 120).

Untuk membuat sebuah konsep dakwah yang menarik dan dapat diterima masyarakat, perlu penguatan dari sisi teknologi dan pihak pengelola terkait. Dakwah melalui pemanfaatan media komunikasi dan teknologi akan lebih mudah mencapai sasaran karena beda generasi beda pula cara pendekatan yang digunakan. Kerjasama partisipatif dengan semua unsur masyarakat harus dilakukan dengan sepenuh hati sehingga masing-masing pihak bersedia aktif dan berkomitmen memberikan kontribusi sesuai dengan bidang masing-masing. Penelitian ini bertujuan untuk mendeskripsikan manajemen komunikasi yang terjadi antar crew MAJT TV bersama dengan pengelola dalam menciptakan program-program dakwah melalui televisi dan juga media baru sebagai kanal menyampaikan informasi kepada masyarakat.

Program Dakwah On TV merupakan program yang mengemas kegiatan-kegiatan dakwah yang melibatkan para ulama yang tergabung dalam Majelis Ulama Indonesia Jawa Tengah dimana sebelumnya hanya berkonsep off air untuk kemudian dikemas dalam bentuk on air, baik itu melalui siaran televisi maupun pemanfaatan media sosial Crew MAJT TV yang masih merupakan mahasiswa berhasil "memindahkan" program dakwah konvensional tatap muka secara langsung untuk dikemas dalam bentuk program dakwah untuk konten televisi maupun media sosial.

Pemilihan Masjid Agung Jawa Tengah atau MAJT sebagai objek kajian penelitian karena merupakan representasi masjid yang menjadi pusat kajian dan pengembangan Islam nusantara dalam skala internasional yang diharapkan akan menjadi rujukan atau simbol perkembangan Islam modern di Indonesia khususnya di Jawa Tengah. Terlebih sekarang ini Masjid Agung Jawa Tengah memiliki sejumlah media komunikasi massa seperti radio DAIS dan MAJT TV yang dijadikan sebagai alat propaganda di dalam memberitakan, melaporkan, 
mempromosikan dan melibatkan ulama maupun masyarakat dalam setiap kegiatan dakwah yang dilakukan melalui sejumlah media massa tersebut.

\section{Kerangka Teori}

Teori Difusi Inovasi

Menurut Rogers dan Singhal dalam (2004), difusi atau diffusion adalah the process by which an innovation is communicated through certain channels over time among the members of a social system, yaitu proses dimana suatu inovasi dikomunikasikan melalui saluran tertentu pada waktu tertentu diantara para anggota sistem sosial. Suatu inovasi adalah an idea, practice, or object perceived as new by an individual or the other unit adoption, yaitu suatu gagasan, perbuatan atau objek yang dipahami sebagai hal baru oleh unit penerimaan individual lainya. Teori difusi inovasi menyatakan bahwa suatu inovasi (misalnya gagasan, teknologi baru, teknik baru dan lain-lain) menyebar dalam pola yang dapat diperkirakan.

Beberapa orang akan segera mengadopsi atau menerima suatu inovasi begitu mereka mengetahuinya, sementara orang lain membutuhkan waktu lebih lama untuk mencoba sesuatu yang baru, sedangkan kelompok lainya lagi membutuhkan waktu yang lebih lama lagi, begitu seterusnya.

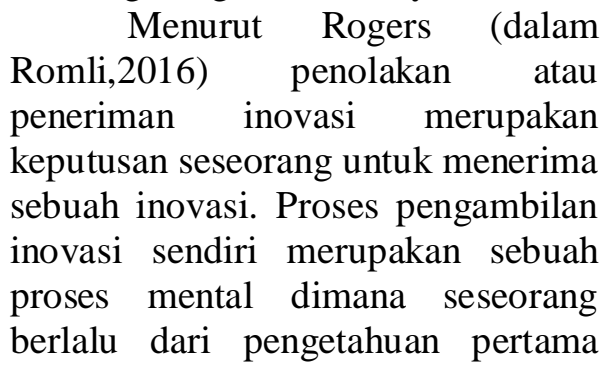

mengenai suatu inovasi untuk membentuk sikap terhadap inovasi, hingga akhirnya memutuskan untuk menerima atau menolak, melaksanakan ide baru dan mengukuhkan terhadap suatu keputusan inovasi (Rogers:1983). Inovasi harus secara signfikan dapat memberikan nilai bertambahnya kesejahteraan yang direprentasikan pada layak jual (diterima pasar) atau tidaknya produk inovatif tersebut. Inovasi berhubungan erat dengan kemampuan untuk memahami kebutuhan maupun keinginan konsumen. Inovasi juga berkaitan erat dengan sikap kreatif, yaitu sikap yang selalu merasa tidak puas dengan pendekatan yang lama, yang dikemas dan disampaikan melalui sarana teknologi yang lebih baik.

Berikut tahapan-tahapan yang muncul dalam proses difusi inovasi tersebut: Tahap Mengadopsi. Adapun beberapa tahapan untuk mengadopsi suatu inovasi menurut Rogers (dalam Romli, 2016), yaitu: Tahap Kesadaran (Awareness), Tahap Keinginan (Interest), Tahap Evaluasi (Evaluation), Tahap Mencoba (Trial), Tahap Adopsi (Adaption).

Karakteristik inovasi merupakan sifat dari difusi inovasi, dimana karateristik inovasi merupakan salah satu yang menjadi penentu kecepatan suatu proses inovasi. Rogers (dalam Romli, 2016) mengemukakan 5 karakteristik inovasi, yaitu: Keuntungan (Relative Advantage), keserasian (compatibility), Kerumitan (Complexity) merupakan sebuah tingkat kerumitan dari inovasi untuk diadopsi, Dapat diuji coba 
(Triability) dan Observasi (Observability).

\section{Metode Penelitian}

Penelitian ini menggunakan pendekatan kualitatif dengan metode studi kasus. Penelitian ini bertujuan untuk menjelaskan bagaimana proses inovasi yang dilakukan oleh remaja masjid yang dipercaya mengelola MAJT TV melalui proses pengumpulan data di lapangan dengan proses wawancara. Peneliti ingin menggambarkan hasil temuantemuan fakta bagaimana generasi muda yang diwakili oleh sejumlah remaja masjid dalam berinovasi memproduksi program dakwah yang berkonsep modern dengan melibatkan media elektronik maupun new media di dalam penerapannya. Objek konten yang menjadi sampel penelitian adalah program Dakwah On TV yang ada di Masjid Agung Jawa Tengah Semarang yang kemudian di broadcast melalui siaran TVKU dan platform social media.

Program Dakwah On TV merupakan program kajian agama tematik berkala yang rutin diselenggarakan di Masjid Agung Jawa Tengah. Pada penelitian ini, data primer diperoleh dari produser program dan empat orang remaja masjid yang sehari-harinya bertugas di MAJT TV dengan berbagai posisi atau job desk yang berbeda-beda mulai dari pengarah acara, kreatif, script writer, editor, dan bagian tehnik. Teknik pengumpulan data dilakukan melalui teknik wawancara dan observasi. Wawancara dilakukan dengan kepala bagian pemasaran dan kehumasan MAJT, serta empat orang crew dari MAJT TV. Observasi dilakukan dengan pengamatan kegiatan secara langsung yang dilakukan oleh para crew MAJT TV dalam memproduksi kegiatan program dengan mengamati adanya perilaku yang tampak dan adanya tujuan yang ingin dicapai.

\section{Hasil Penelitian dan Pembahasan}

Berikut ini deskripsi dan karakteristik dari informan yang menjadi subjek penelitian :

1. Informan pertama adalah Beni (32 tahun), manager humas dan pemasaran MAJT. Bagian ini menurut struktur organisasinya membawahi jalannya pemasaran dan fungsi kehumasan termasuk publikasi dan media yang didalamnya terdapat radio DAIS dan MAJT TV.

2. Informan kedua adalah Dadang (22 tahun) dengan latar belakang mahasiswa Fakultas Dakwah dan Komunikasi UIN Walisongo. Seorang produser yang mampu memimpin. Jika melihat pola kerja dalam televisi sebagai tim maka sebagai produser harus bertanggung jawab mulai dari pra produksi hingga paska produksi. Kemampuan manajerial disertai kemampuan komunikasi menjadi kriteria yang dimilikinya.

3. Informan ketiga adalah Muhammad Syamsul Ma'arif (21 tahun) dengan latar belakang mahasiswa Fakultas Dakwah dan Komunikasi UIN Walisongo Semarang. Informan kedua ini memiliki kompetensi dibidang tehnik, sehingga yang bersangkutan dipercaya sebagai tehnical support MAJT TV.

4. Informan keempat adalah Oriza Sativa (21 tahun) dengan latar belakang mahasiswa Fakultas 
Dakwah dan Komunikasi UIN Walisongo Semarang. Karakteristik kompetensi yang dimiliki informan ketiga ini adalah sebagai juru masak acara atau biasa disebut tim kreatif di MAJT TV. Dimana tugas pokoknya, menciptakan menu dalam hal ini konsep acara televisi untuk dijabarkan oleh produser.

5. Informan kelima adalah Firyal (22 tahun) dengan latar belakang mahasiswa Fakultas Dakwah dan Komunikasi UIN Walisongo Semarang. Posisinya sebagai seorang video editor program di MAJT TV, dituntut memiliki kesadaran atau cita rasa yang kuat, serta sikap kreatif dalam menyusun shotshot gambar setelah proses produksi.

\section{Analisis Temuan Penelitian}

Informan: Beni- Kepala Humas dan pemasaran MAJT

\section{Dakwah On TV sebagai bagian inovasi dakwah}

Hadirnya konsep dakwah $O N T V$ sebagai bentuk baru terobosan peralihan model dakwah konvensional menjadi bentuk dakwah modern dalam kemasan broadcast. Jika biasanya dakwah hanya sekedar tatap muka antara penceramah dengan jamaah, dalam konsep ini dakwah bertransformasi pada tatanan konsep agar lebih nyaman untuk bisa dinikmati dalam bentuk format kebutuhan televisi maupun sosial media. Selalu terdapat nilai kebaruan yang hadir dalam inovasi, menjadi ciri yang membedakan hal lainya (Suwarno, Yogi. 2008).

Apa yang terjadi dalam inovasi di sini menunjukkan bahwa telah terjadi faktor pembeda dengan konsep inovasi sebelumnya. Inovasi hanya dapat diterima apabila telah terbukti dan teruji memiliki nilai lebih atau keuntungan dibandingkan inovasi sebelumnya. Produk inovasi dapat di uji pada setiap orang melalui fase "uji publik" (Suwarno, Yogi. 2008).

Inovasi dalam program Dakwah ON TV ini membawa konsekuensi tampilan program mempengaruhi kelayakan untuk ditampilkan dalam bentuk tampila program televisi maupun kebutuhan sosial media. Kehadiran remaja masjid sebagai agen pelaksana di lapangan dianggap mampu menerjemahkan arti dari inovasi dalam membuat konten yang layak dan menarik untuk di tonton. Sebagaimana ditegaskan oleh informan bernama Beni bagaimana seharusnya anak-anak muda yang terwakili sebagai bagian remaja masjid memberikan kontribusi yang luar biasa yang melatarbelakangi mengapa Masjid Agung Jawa Tengah perlu memberdayakan anakanak muda untuk terlibat.

"Pemberdayaan anak muda dalam MAJT TV diperlukan dikarenakan saat ini MAJT $T V$ sedang dalam proses perintisan perijinan $T V$, dengan pemberdayaan Anak muda diharapkan dakwah yang ditujukan kaum milenial lebih mengena"-Beni. (Wawancara mendalam, 5 Oktober 2019)".

Informan Sativa sebagai bagian dari personil MAJT TV memahami tugas yang diberikan kepadanya. Bahwa dirinya bertanggung jawab atas sejumlah tugas yang diberikan kepadanya. 
"Tugas saya ada di bagian produksi. Take gambar untuk program program MAJTTV. Backup data hasil gambar ke komputer. Memegang kas MAJTTV"- Sativa

Hampir senada dengan jawaban informan sebelumnya, informan berikutnya Firyal juga menyatakan sudah memahami apa yang menjadi tugasnya di MAJT TV.

"Memilih program-program yang telah disediakan dalam komputer yang setelah sebelumnya di produksi oleh tim produksi Menyunting gambar-gambar dan atau audio dalam video Menggabungkan gambar dan audio menjadi satu padu hingga tercipta satu segmen atau beberapa segmen Mengkategorisasi programprogram"-Firyal.

Menurut hasil analisa tentang pemahaman informan mengenai tanggung jawab dan tugasnya sebagian besar sudah memahami tugas dan job desknya pada MAJT TV setiap harinya. Pada tahap selanjutnya terdapat tahap menafsirkan atau interpretation. Tahap ini lebih luas dari menerjemahkan, dimana pada tahap ini para crew tidak hanya sebatas menerjemahkan saja, melainkan juga memikirkan dan mendesain untuk kemudian menentukan jenis program dakwah yang menarik untuk bisa dikemas dalam bentuk broadcast.

Berikut kutipan hasil wawancara informan Syamsul yang melihat adanya kendala dalam menerjemahkan inovasi yang dimaksud.

"Kendala yang dijumpai ialah, sebagian besar belum maksimal dalam menyupport dari para pengurus tentang kemajuan teknologi, ide dan gagasan. Sehingga terkadang grand design yang sudah dicetuskan terkadang mentah di atasan alias hasilnya tidak seperti yang diharapkan"syamsul.

Sativa menyatakan bahwa tidak semua hasil akhir dari proses yang diupayakan dalam setiap produksi selinier dengan tujuan program.

"Tidak semua berjalan lancar. Inovasi dan ide yang diajukan dari crew terkadang berbenturan dengan kemauan para pengurus MAJT. Take produksi pun harus mengikuti kehadiran narasumber. Kalau narasumber tidak bisa, maka program tidak bisa produksi”

Selanjutnya terdapat sebuah tahap mengekstrapolasi atau extrapolation yang merupakan tahap terakhir pada tingkat pemahaman. Pada tingkat ini para crew MAJT TV dituntut memiliki kemampuan intelektual yang tinggi untuk melihat lebih detail tentang kebutuhan program broadcast itu seperti apa seharusnya. Pada tingkat pemahaman dan pengembangan ide dan gagasan inovasi para crew mampu melakukan namun mereka tidak bisa melanjutkan inovasi tersebut jika ternyata bertentangan dengan kepentingan dari Masjid Agung Jawa Tengah. 


\section{Karakteristik Program Dakwah ON TV}

Karakteristik sebuah program akan menentukan minat dan karakter dari para penontonnya, mengapa demikian semakin berkarakter program yang ditampilkan maka akan semakin banyak yang menonton. Para penonton beranggapan bahwa dengan melewatkan tayangan atau tontonan tersebut maka akan menimbulkan kerugian dalam pribadi individu tersebut. Rogers (dalam Suwarno, 2008) mendefinisikan inovasi merupakan praktek, objek atau ide yang dianggap baru bagi inividu satu unit adopsi lainya. Karakteristik inovasi berupa Keuntungan relatif (relative advantage disampaikan oleh informan Beni berikut ini:

"gagasan program dari MAJT TV di dalam pelibatan ulama dan masyarakat melalui program yang bekerja sama dengan berbagai pihak seperti MUI dll memberikan warna baru dari model dakwah yang dilaksanakan di MAJT serta memberikan media baru bagi MAJT untuk menjangkau lebih banyak masyarakat dan memenuhi media publikasi yang telah ada

Muncul perbandingan juga dalam konsep dakwah di MAJT yang disampaikan oleh informan ketika kehadiran MAJT TV dianggap sebagai bagian dari media penyampai dakwah.

"Sebelum ada MAJT TV,
MAJT

dokumentasi internal di bidang fotografi. Media yang di punya biasanya cetak dan radio dais. Dengan adanya MAJTTV tentu menambah keragaman media yg hadir di MAJT. Dan menjangkau masyarakat lebih luas lagi, dan menyebarkan islam lbh besar lagi lewat medsos medsos yang ada"-Sativa..

Dapat disimpulkan bahwa ada keuntungan relatif dari hadirnya inovasi dalam bentuk program dakwah ON TV di Masjid Agung Jawa Tengah.

Kerumitan (Complexity), bahwa tingkat kesulitan produksi yang dihadirkan dalam produksi dakwah ON TV ini cenderung bervariasi, mulai dari koordinasi acara, pengaturan narasumber, setting alat dan tempat termasuk juga ketika dilapangan ditemukan persoalan yang diluar perencanaan. Berikut hasil kutipan wawancara Firyal tentang kerumitan proses produksi:

“Tim produksi
mengkonfirmasi para
narasumber setiap harinya
baik dihubungi langsung oleh
narasumber dan atau tim
produksi menanyakan kepada
narasumber, jika memang ada
kedapatan narasumber, tim
produksi langsung
mengarahkan timnya dalam
proses produksi. Jika tim
produksi selesai dalam proses
produksi, data mentah yang
sebelumnya terdapat dalam
kamera disalin kedalam data
komputer dan dinamai setiap
programnya, kemudian tugas


editor menyeleksi dan menggabungkan video tersbu" Kecepatan produksi yang meliputi pra dan pasca produksi menjadi sebuah tantangan. Perlu adanya kerjasama bersama antara tim tehnis crew MAJT TV dengan pengelola masjid baik dalam penataan tempat, alat pendukung dan lain sebagainya.

Kemungkinan dicoba (Triability), salah satu informan telah melakukan kemampuan uji coba pada program dakwah ON TV ini apakah inovasi yang dilakukan terhadap program tersebut bisa secara cepat di adopsi oleh masyarakat termasuk juga para kyai yang menjadi narasumber.

"Konsep modern yang mampu diterima masyarakat ialah Konten Dakwah yang berisikan tentang keseharian masyarakat tentang norma, sosial, tingkah laku, serta isu yang dihadapi oleh masyarakat yang didalamnya dibahas berdasarkan aturan atau norma serta kaidah dalam beragama. Hal tersebut dapat diwujudkan dengan konten-konten era sekarang yang lebih difokuskan pada sisi digital, contohnya tanya jawab yang didesain sedemian rupa sehingga dengan mudah dipahami baik kaum muda atau masyarakat yang sudah berkeluarga"-Firyal.

Jawaban lainnya disampaikan oleh informan Syamsul yang menyatakan bahwa tangapan ulama sebagai penceramah mempertanyakan kecepatan akan kepastian tayang ulang hasil produksi program yang dilakukan seusai mengisi acara dakwah yang di produksi oleh MAJT TV.

"Tanggapan ulama cukup beragam namun sebagian besar cukup positif, hanya saja ada beberapa ulama yang menanyakan jadwal tayang. Hal tersebut tidak bisa serta merta kami jawab untuk menjanjikan kapan tayang, karena hasil dari produksi harus diolah dulu sebelum akhirnya ditayangkan. Biasanya kami menyetok dulu hasil program kalau sudah mencukupi baru dikirim ke TVKU untuk ditayangkan"

Secara umum bahwa sejumlah informan mengatakan tanggapan positif dari masyarakat maupun para ulama sebagai pengisi acara sekalipun masih belum ada kepastian akan kejelasan jadwal tayang dari program yang sudah diproduksi oleh MAJT TV.

Kemampuan

diamati (Observasibilitas) menunjukan bahwa kegiatan ceramah atau dakwah rutin di Masjid Agung Jawa Tengah yang bersifat audio visual selama ini cukup banyak namun belum terdokumentasikan dan terdistribusikan dengan baik. Bahwa selama ini sebelum ada kehadiran MAJT TV untuk acara pendokumentasian kegiatan memanfaatkan pihak vendor dari luar masjid. Kebiasaan ini terjadi karena digitalisasi kegiatan masih belum terlalu dianggap penting di Masjid Agung Jawa Tengah saat itu. 


\section{Proses Keputusan Adopsi Inovasi Dakwah}

Adopsi merupakan reaksi yang muncul atau timbul dari para remaja masjid ketika mereka menemukan respon yang berbeda dalam setiap kegiatan produksi yang dilakukan. Proses Keputusan Adopsi Melalui Lima Tahapan berikut ini:

\section{- Tahap pengetahuan}

Pada tahap ini, sejumlah informan mengetahui adanya inovasi dan fungsi dari inovasi program dakwah rutin yang dilakukan di Masjid Agung Jawa Tengah. Tahap pengetahuan juga mencakup tentang tujuan dari program. Pengetahuan Informan Beni berkait maksud dan tujuan dari program ini:

"Adanya keterlibatan pihak TVKU dan pola kemitraan antara MAJT dengan TVKU dalam pembuatan konsep dakwah yang modern di MAJT selama ini, pola kemitraan yang terjalin antara $T V K U$ dan MAJT adalah kerjasama yang saling menguntungkan dimana keduanya saling mengisi kekurangan yang ada, seperti kurangnya tenaga ahli tentang pertelevisian di MAJT dan TVKU mendapatkan produksi program yang bisa ditayangkan di TVKU"-Beni.

Beni memahami, latar belakang dan mengerti maksud dari tujuan inovasi dalam program dakwah ini, namun demikian program ini tidak akan berjalan baik jika tidak ada kolaborasi Bersama dengan TVKU Semarang.

Menurut informan Sativa, bahwa keberadaan MAJT TV sangat menopang keberlangsungan model dakwah modern yang seharusnya itu sejak lama terjadi di Masjid Agung Jawa Tengah.

"Sangat strategis. Karena jelas MAJTTV punya identitas sebagai tv yang fokus pada dakwah islam. Dan itu tidak dipunyai tv lokal lain, di semarang khususnya. Tapi tentu perlu SDM yang memadai, dan manajemen yang baik"-Sativa.

Melihat pemahaman dari sejumlah informan dapat disimpulkan bahwa dalam melaksanakan kegiatan produksi program dakwah ON TV membuat sebuah kesadaran kolektif adanya pemanfaatan media broadcast dan Kerjasama dengan banyak pihak dalam memfasilitasi giat dakwah yang ada di Masjid Agung Jawa Tengah. Sejauh ini hasil penelitian menujukkan bahwa dua orang informan memahami betul pengetahuan tentang inovasi yang mereka lakukan.

\section{- Tahap Persuasi}

Pada tahap ini, para remaja masjid ini mulai muncul tahap kritis dalam diri mereka apakah model dakwah yang mereka buat dapat memberikan pengaruh kepada masyarakat. Selain itu, bagaimana formal ideal dakwah yang cocok untuk masjid sekelas Masjid Agung Jawa Tengah itu seperti apa.

"Yang menarik, kreatif, edukatif. Tidak hanya satu arah tapi bisa dua arah komunikasinya. Bisa diterima berbagai golongan. Bersifat menyatukan bukan memecah belah golongan tertentu. Yang 
damai dan rahmatan lil alamin"-Sativa.

Pendapat kritis yang hampir bernada sama juga disampaikan oleh informan Firyal, bahwa kalau ingin masyarakat menerima dakwah sebaiknya disesuaikan dengan kebutuhan masyarakat.

"Dikemas dengan balutan halhal yang tidak mendoktrinkan sesuatu atau menjudge keyakinan lain, menyesuaikan kondisi dan segementasi masyarakat, mengambil tema tentang fenomena yang sedang terjadi lalu diimplementasikan dalam sebuah program yang mengandung dakwah sesuai dengan kaidah Islam baik AlQur'an maupun hadits"Firyal.

"Konsep perencanaan desain program MAJT TV tidak terlepas dari Dakwah Rahmatan Lil Alamin yang mendukung proses pengembangan MAJT sebagai pusat peradaban Islam moderat. Dalam prakteknya kami mencoba mengemas Dakwah yang mampu segala lapisan masyarakat baik generasi milenial maupun generasi yang lebih tua"Syamsul.

Secara keseluruhan dapat disimpulkan bahwa tiga orang informan mengatakan bahwa dakwah yang baik itu menyesuaikan situasi dan kondisi, dilakukan dua arah, dan pengemasan yang menarik. Pada tahap persuasi ini, membentuk sikap dari informan untuk meyakini bahwa dakwah itu tidak cukup hanya mengandalkan sosok sehingga perlu adanya inovasi.

\section{- Tahap Keputusan}

Tahap keputusan dari sebuah proses inovasi terjadi disaat ada kendala yang membuat terganggunya proses inovasi dakwah yang dilakukan. Pada prinsipnya tidak semua inovasi dapat diterima dengan baik oleh banyak pihak. Pada tahap proses keputusan inovasi produksi program dakwah ON TV terdapat sejumlah tahapan yang menurut informan. Sejumlah persoalan muncul diantaranya:

"Proses pengambilan

keputusan dalam pembuatan program terdiri dari rapat tim produksi, selanjutnya hasil dari rapat tersebut disampaikan kepada Koordinator/Direktur untuk dilakukan sebuah keputusan"Beni

Terdapat tahapan yang dibuat dalam pengambilan keputusan baik pra acara, produksi acara maupun pasca acara. Namun demikian berkait dengan siapa yang menjadi penceramah dari Masjid Agung Jawa Tengah, pihak pengurus menetapkan standar tinggi dalam pemilihannya dan tidak bisa diintervensi.

"MAJTTV menyesuaikan agenda-agenda yang terdapat dalam lembaga MAJT sendiri disamping itu menjadi kemudahan bagi MAJTTV dalam proses produksi. MAJT telah menyiapkan narasumber yang bisa dibilang pakarnya, melihat perkembangan para narasumber yang notabene para kyai dengan penyampaian pesan yang 


$\begin{array}{lr}\text { berbedariap } & \text { setiap } \\ \text { narasumbernya, MAJT selektif } \\ \text { dalam memilih para } \\ \text { narasumber, sebab itu } & \text { tidak } \\ \text { sembarangan } & \text { MAJT } \\ \text { menyiapkan } & \text { para } \\ \text { narasumber"-Syamsul. } & \end{array}$

Setiap keputusan yang sebelumnya direncanakan terkadang tidak sesuai dengan praktik dilapangan. Sehingga keputusankeputusan taktis harus segera diputuskan oleh mereka yang di lapangan.

"Setiap perencanaan yang
dilakukan terkadang tidak
selalu linier dengan hasil
akhir, biasanya hal itu terjadi
karena adanya kendala teknis
listrik mati, sound system yang
tak bekerja maksimal ataupun
narasumber yang terkadang
tidak hadir"Firyal.

Pada hasil penelitian, terdapat tiga informan yang memiliki pendapat cukup berbeda. Salah satunya ketika persoalan tehnis harus segera diputuskan tanpa harus menunggu keputusan dari pengurus Masjid Agung Jawa Tengah Ketika ditemukan persoalan di lapangan.

\section{- Tahap Implementasi}

Tahap implementasi pada proses keputusan inovasi terjadi jika seseorang menerapkan sebuah inovasi. Keputusan penerima gagasan atau ide baru dibuktikan dalam praktek. Implementasi ini terwakili dalam jawaban-jawaban yang diberikan informan sebagai berikut:

"Bisa diterima, setiap live yang kami adakan banyak jamaah yang memberi tanggapan. Subsribers dan followers di medsos terus bertambah" Sativa.

Respon positif dari ulama juga diberikan lewat informan Firyal, bahwa apresiasi yang diberikan ulama sangat memberikan energi positif terhadap kinerja dari para informan.

"Para Ulama mengapresiasi kerja kru TV meskipun banyak kekurangan didalamnya dalam menyampaikan pesan dari para da'i, sehingga para kru TV untuk dapat lebih baik dalam pelaksanaan proses dakwah tersebut dari hari ke hari”-Syamsul.

Implementasi keterlibatan masing-masing individu dari informan dalam setiap eksekusi atau pelaksanaan dari setiap program kegiatan produksi program menjadi bukti Kerjasama yang baik sebagai tim.

"Tim produksi memproduksi setiap program-program yang telah disepakati sebelumnya, terkadang juga tim produksi meminta bantuan kepada tim lainnya untuk membantu proses produksi. Keseluruhan tim harus memiliki kemampuan multitasking sehingga dapat mempermudah jalannya sebuah produksi baik dari pra produksi, produksi, hingga pasca produksi”Firyal.

Hasil penelitian membuktikan bahwa keputusan inovasi pada tiga informan dapat diimplementasikan dalam bentuk kemampuan multitasking dari setiap diri informan.

\section{- Tahap (Confirmation)}


Pada tahap konfirmasi, informan mencari sebuah penguatan untuk keputusan yang telah diambil dan informan dapat menarik kembali keputusanya jika memperoleh informasi lain yang bertentangan dengan informasi awal. Bahwa informan Beni menyatakan kerjasama tim bisa terbangun dengan baik ketika terjadi komunikasi yang baik antara pengurus dan para remaja masjid.

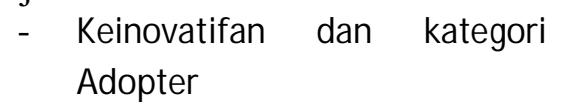

Keinovatifan dan Kategori adopter digolongkan menurut kecepatan peran informan dan penerimaan dalam keberadaan inovasi dalam pelaksanaan program dakwah ON TV. Informan yang dikelompokan kedalam anggota kategori adopter adalah para remaja masjid yang berlatar belakang mahasiswa yang sehari-harinya berkecimpung di MAJT TV. Hasil penelitian menunjukkan dari empat informan hampir keempatnya memiliki ketertarikan dibidang penyiaran atau broadcasting.

"tugas saya setiap harinya memilih program-program yang telah disediakan dalam komputer yang setelah sebelumnya di produksi oleh tim produksi Menyunting gambar-gambar dan atau audio dalam video Menggabungkan gambar dan audio menjadi satu padu hingga tercipta satu segmen atau beberapa segmen Mengkategorisasi programprogram"-Firyal.

"Untuk keterlibatan Individu dalam eksekusi sudah sesuai dengan SOP yakni, Tim Produksi membuat produksi berupa hasil rekaman video, selanjutnya dari Tim Produksi diserahkan kepada Editor untuk mengolah gambar video selanjutnya dibagi persegmen jumlah total 5 segmen, dari Editor diserahkan kepada TS/IT untuk dicek ulang dari situ apabila sudah sesuai hasil dokumentasi tersebut di kirim ke Cloud TVKU untuk ditayangkan sesuai jadwal yang berlaku"-Syamsul.

Sementara itu, dua informan lainnya berani membandingkan keinovativan atau kehadiran dari sebelum ada MAJT TV maupun setelah ada MAJT TV terlebih dalam warna dakwah di Masjid Agung Jawa Tengah.

"Dulunya konsep dakwah di MAJT hanya mampu didengarkan via Radio namun semenjak MAJT TV hadir dipertengahan 2017. Kajian di MAJT Sekarang dapat dinikmati baik melalui Radio, Siaran TV, hingga konten di Media Sosial".Sativa.

"Konsep yang ditawarkan MAJT TV sebagai Televisi yang berbasis Dakwah cukup diterima dengan Baik oleh Masyarakat, terbukti kurang dari 2 Tahun berdiri viewers di Media Sosial yang dimiliki naik ke tajam meskipun sewaktu-waktu kadang turun namun secara rata-rata kenaikan cukup dinamis"-Firyal. "Saya rasa cukup bagus untuk kedepannya sebab TVKU sebagai Televisi Pendidikan dan MAJT sebagai Tempat ibadah yang mengembangkan islam moderat, dan hadirnya program-program MAJT TV bernafaskan Dakwah 
Islami Masa kini, saya rasa akan mampu menjawab tantangan zaman dan tentunya keperluan masyarakat."-Syamsul.

Kutipan wawancara diatas menujukkan bahwa tiga informan memiliki rasa optimisme tinggi dalam mengawal proses inovasi dakwah di Masjid Agung Jawa Tengah. Hal ini ditentukan secara teori penerimaan inovasi para informan tersebut masuk kedalam kategori tipe cepat mengadopsi perubahan yang terjadi.

\section{Partisipasi remaja masjid dalam inovasi program dakwah}

Melihat seberapa besar peran serta dari para remaja masjid dalam menerapkan inovasi pada program dakwah digital di Masjid Agung Jawa Tengah melalui program dakwah ON TV menjadi tujuan akhir dari penelitian ini. Berikut ini analisa berdasarkan hasil penelitian wawancara dengan sejumlah informan:

\section{Bentuk Partisipasi}

- Partisipasi dalam bentuk ide kreatif

Sejumlah remaja masjid dalam kegiatannya sudah memberikan inovasi baru dalam bentuk dakwah baru dari bentuk konvensional menjadi digital. Dari hasil penelitian ini, partisipasi dalam inovasi ditunjukkan dalam bentuk ide program yang mengacu pada partisipasi keterlibatan mereka dalam ikut merubah, memberikan masukan kepada pengurus, termasuk memberian usulan-usulan berkait pertimbangan bagaimana bentuk ideal sebuah program yang disiarkan televisi itu seharusnya seperti apa sehingga bisa diterima dan dinikmati oleh masyarakat secara luas.

- Partisipasi masyarakat dalam bentuk kegiatan

Sementara itu, partisipasi selanjutnya adalah partisipasi melalui bentuk keterlibatan dalam kegiatan. Keterlibatan ini dari hasil pengamatan dan wawancara dapat disimpulkan bahwa totalitas keberhasilan dari model program dakwah ini tidak bisa lepas dari keterlibatan langsung dalam proses produksi yang dilakukan para remaja masjid ini. Hal ini bisa dilihat dari pra produksi seperti persiapan infrastruktur alat mulai dari penataan kamera, instalasi kabel, mixer, switcher dan alat lainnya. Sedangkan untuk produksi terlihat dengan dengan jelas bagaimana masingmasing dari remaja masjid ini tampil sebagai eksekutor langsung di lapangan mulai dari produser, kreatif, cameramen, soundman. Untuk pasca produksi dapat dilihat dari proses QC atau quality control mulai dari editing hingga pengunggahan file di social media maupun penayangan di televisi.

- Partisipasi dalam bentuk kerjasama antar bagian

Bukan tidak mungkin bahwa proses broadcasting yang dikenal kompleksitasnya dengan segala infrastruktur dan keterlibatan profesional di dalamnya terlihat begitu simple atau sederhana dalam proses kegiatan penyiaran yang dilakukan oleh sejumlah remaja masjid di Masjid Agung Jawa Tengah. Bahwa ternyata aktivitas produksi program yang dilakukan juga didukung oleh komunikasi yang 
baik dengan unit bagian pengelola masjid lainnya. Sebagai contoh yaitu dukungan infrastruktur sound system yang baik, pencahayaan tata lampu ruangan yang ideal menjadikan hasil produksi program dakwah ON TV yang dilakukan oleh para remaja masjid tersebut menjadi layak atau nyaman untuk dinikmati.

\section{- Lima tingkatan partisipasi}

Terdapat lima tingkatan partisipasi, meliputi memberikan informasi, konsultasi, pengambilan keputusan bersama, bertindak bersama dan memberikan dukungan, hal ini sesuai dengan teori yang dikemukakan oleh Wilcox dalam Theresia (2014:202).

1) Memberikan Informasi

Kehadiran program dakwah ON TV yang mengakomodir kajian dakwah rutin di Masjid Agung Jawa Tengah menjadi kemasan program modern yang bisa dinikmati masyarakat melalui sejumlah platform media social dan juga televisi sepertinya menjadi sebuah jawaban kebutuhan inovasi dakwah. Inovasi ini bisa menjadi salah satu faktor penunjang yang menjawab kebutuhan akan informasi di masyarakat. Proses komunikasi akan terus terjadi ketika terpaan program menyasar kepada public melalui media yang mudah diakses setiap saat. Menurut hasil penelitian yang dilakukan, partisipasi remaja masjid di Masjid Agung Jawa Tengah dalam berkontribusi memberikan informasi kepada masyarakat luas sangat berperan penting di dalamnya. Tiga orang informan mengklaim bahwa kehadiran program dakwah digital di Masjid Agung Jawa Tengah tergantung pada peran serta yang mereka lakukan selama ini.

2) Konsultasi (consultation)

Pada pengembangan sebuah inovasi, hal yang terpenting dilakukan adalah terjadinya proses

komunikasi dua arah dalam bentuk konsultasi yang dilakukan antara remaja masjid sebagai bagian dari tim produksi dengan pihak pengurus masjid sebagai pihak pengarah. Dari hasil penelitian ini, sepertinya proses konsultasi yang terjadi cenderung kurang maksimal dan hanya berhenti pada tatanan penentuan narasumber dari pengurus tapi tidak sampai kepada pembahasan evaluasi bagaimana paket program selama ini berjalan. Hal ini terjadi karena masih minimnya pemahaman ilmu broadcasting dikalangan pengurus masjid.

3) Pengambilan keputusan bersama (deciding together)

Pada hasil penelitian, pengambilan keputusan siapa yang mengisi atau menjadi narasumber program dakwah ON TV menjadi hak prerogative dari pengurus masjid. Artinya remaja masjid sebagai pelaksana tidak memiliki kewenangan untuk ikut menentukan siapa yang menjadi narasumber. Sejumlah informan juga mengakui 
bahwa inovasi terlebih berkait dengan usulan narasumber yang milenial sebagaimana diharapkan oleh remaja menjadi sangat sulit terealisasi. Empat informan juga sepakat bahwa inovasi materi dakwah tergantung pada keputusan pengurus. Para informan ini juga tidak bisa membuat keputusan langsung jika mendadak narasumber yang dipilih oleh pengurus tiba-tiba tidak hadir dikarenakan sejumlah alasan.

4) Bertindak Bersama

Tindakan bersama dalam inovasi kegiatan dilakukan secara solid oleh para informan. Namun demikian bertindak bersama tersebut hadir dalam kegiatan produksi tapi tidak dalam tataran pengambilan keputusan untuk menentukan siapa yang akan menjadi narasumber. Arti dari bertindak bersama menurut Wilcox (1998) dalam Aprilia Theresia (2014:202), adalah tidak hanya sekadar ikut pada pengambilan keputusan saja, akan tetapi terlibat pada pelaksanaanya.

5) Memberikan dukungan (supporting independent community interest)

Partisipasi dalam tingkatan ini mayoritas pengurus memberikan dukungan pelaksanaan kegiatan produksi program dakwah ON TV, hal ini juga terlihat pada dukungan semua bagian usaha yang ada di Masjid Agung Jawa Tengah dalam ikut menyukseskan produksi program tersebut. Namun demikian dapat disimpulkan dukungan ini dapat diartikan dukungan yang ada ramburambu batasan yang itu harus dipatuhi oleh mereka para remaja masjid sebagai pelaku di lapangan.

\section{Faktor Penghambat partisipasi}

Sejumlah indikator yang menjadi faktor penghambat partisipasi seperti sifat apatis, malas dan tidak mau melakukan perubahan, faktor aspek tipologis, faktor geografis, faktor demografi dan faktor ekonomi, dapat disimpulkan bahwa hal ini tidak atau belum ditemukan di kalangan remaja masjid di Masjid Agung Jawa Tengah hal ini dapat dilihat dari konsistensi dan kontinuiti produksi kegiatan dakwah yang rutin dilakukan. Sementara itu faktor tidak adanya tindakan perubahan untuk mengembangkan dan memanfaatkan inovasi juga sangat kecil. Dari lima orang informan hamper semuanya sepakat untuk terus mengembangan inovasi dakwah modern di Masjid Agung Jawa Tengah. Sementara faktor lainya seperti aspek tipologi, letak geografis, jumlah jamaah di Masjid Agung Jawa Tengah tidak signifikan berpengaruh menjadi faktor penghambat. Karena sejak awal komitmen dari para remaja masjid ini dan latar belakang aktivitas mereka ikut menjadi 
faktor pendukung. Kalaupun terdapat hambatan adalah masih minimnya ruang usulan dari remaja masjid kepada pengurus dalam konteks memberikan masukan tentang narasumber.

\section{Pembahasan Temuan Penelitian}

Kontribusi remaja masjid dalam ikut mensiarkan dakwah yang dilakukan ulama menjadi factor yang sangat penting di Masjid Agung Jawa Tengah terlebih dengan mamanfaatkan perkembangan teknologi multimedia sekarang ini. Akan tetapi, pada penelitian ini ditemukan sejumlah persoalan pemberdayaan dalam proses dinamika manajemen organisasi yang di temukan di Masjid Agung Jawa Tengah. Dari lima informan yang diteliti, ke lima diantaranya bergerak Bersama untuk berpartisipasi, hal ini karena niat dan minat ketertarikan mereka dibidang multimedia boardcast menjadi faktor pendukung.

Penelitian partisipasi dan peran serta remaja masjid sebagai bentuk inovasi menunjukkan hasil pemahaman bahwa mereka memahami tugas dan tanggung jawab yang harus mereka lakukan sebagaimana terlihat dari hasil wawancara dari tiga informan firyal, Syamsul dan Sativa.

Pemahaman informan

mengenai tanggung jawab dan tugasnya sebagian besar sudah memahami tugas dan job desknya. Pada tahap selanjutnya terdapat tahap menafsirkan atau interpretation. Tahap ini lebih luas dari menerjemahkan, dimana pada tahap ini para crew tidak hanya sebatas menerjemahkan saja, melainkan juga memikirkan dan mendesain untuk kemudian menentukan jenis program dakwah yang menarik untuk bisa dikemas dalam bentuk broadcast.

Terdapat kendala yang cukup significan dimana dua informan yaitu Syamsul dan Sativa memiliki dua pendapat yang sama bahwa ternyata tidak semua hasil akhir dari proses yang diupayakan dalam setiap produksi selinier dengan tujuan. Dimana program Inovasi dan ide yang diajukan dari crew terkadang berbenturan dengan kemauan para pengurus MAJT. Take produksi pun harus mengikuti kehadiran narasumber. Kalau narasumber tidak bisa, maka program tidak bisa produksi.

Pada tahap persuasi, mulai muncul tahap kritis dalam diri remaja masjid untuk mereka berfikir apakah model dakwah yang mereka buat dapat memberikan pengaruh kepada masyarakat. Selain itu, bagaimana formal ideal dakwah yang cocok untuk masjid sekelas Masjid Agung Jawa Tengah itu seperti apa seharusnya. Tiga informan Syamsul, Firyal dan Sativa berpendapat yang sama bahwa kalau ingin masyarakat menerima dakwah sebaiknya disesuaikan dengan kebutuhan masyarakat.

Dakwah yang baik itu menyesuaikan kondisi dan segementasi masyarakat, mengambil tema tentang fenomena yang sedang terjadi lalu diimplementasikan dalam sebuah program yang mengandung dakwah sesuai dengan kaidah Islam baik Al-Qur'an maupun hadits. Dalam prakteknya para informan mengklaim mencoba mengemas dakwah yang mampu segala lapisan 
masyarakat baik generasi milenial maupun generasi yang lebih tua. Secara keseluruhan dapat disimpulkan bahwa tiga orang informan mengatakan bahwa dakwah yang baik itu menyesuaikan situasi dan kondisi, dilakukan dua arah, dan pengemasan yang menarik. Pada tahap persuasi ini, membentuk sikap dari informan untuk meyakini bahwa dakwah itu tidak cukup hanya mengandalkan sosok sehingga perlu adanya inovasi.

Keinovatifan dan Kategori
adopter digolongkan menurut
kecepatan peran informan dan
penerimaan dalam keberadaan
inovasi dalam pelaksanaan program
dakwah ON TV. Hasil penelitian
menunjukkan dari empat informan
hampir keempatnya memiliki
ketertarikan dibidang penyiaran atau
broadcasting.

$\begin{array}{rrr}\text { Pada } & \text { lima } & \text { tingkatan } \\ \text { partisipasi } & \text { yang } & \text { meliputi }\end{array}$ memberikan informasi, konsultasi, pengambilan keputusan bersama, bertindak bersama dan memberikan dukungan, hal ini sesuai dengan teori yang dikemukakan oleh Wilcox dalam Theresia (2014:202). Dalam konteks memberikan informasi tiga orang informan mengklaim bahwa kehadiran program dakwah digital di Masjid Agung Jawa Tengah tergantung pada peran serta yang mereka lakukan selama ini. Artinya adanya ketergantungan produksi program yang mengandalkan anakanak muda ini. Pada tahapan konsultasi terjadi proses konsultasi yang kurang maksimal dan hanya berhenti pada tatanan penentuan narasumber dari pengurus tapi tidak sampai kepada pembahasan evaluasi bagaimana paket program selama ini berjalan. Hal ini terjadi karena masih minimnya pemahaman ilmu broadcasting dikalangan pengurus masjid. Sedang pada tahapan pengambilan keputusan bersama dari empat informan juga sepakat bahwa inovasi materi dakwah tergantung pada keputusan pengurus. Para informan ini juga tidak bisa membuat keputusan langsung jika mendadak narasumber yang dipilih oleh pengurus tiba-tiba tidak hadir dikarenakan sejumlah alasan. Dalam tahapan bertindak bersama dan memberikan dukungan dapat terlihat dukungan yang diberikan pengurus relatif maksimal (supporting independent community interest) dapat disimpulkan dukungan ini dapat diartikan dukungan yang ada dengan tetap memperhatikan ramburambu batasan yang harus dipatuhi oleh mereka para remaja masjid sebagai pelaku di lapangan.

Menurut hasil penelitian selanjutnya, adapun faktor penghambat partisipasi, peneliti menemukan bahwa tidak atau belum ditemukan di kalangan remaja masjid di Masjid Agung Jawa Tengah hal ini dapat dilihat dari konsistensi dan kontinuiti produksi kegiatan dakwah yang rutin dilakukan. Sementara itu faktor tidak adanya tindakan perubahan untuk mengembangkan dan memanfaatkan inovasi juga sangat kecil.

Dari lima orang informan sepakat untuk terus mengembangan inovasi dakwah modern di Masjid Agung Jawa Tengah. Karena sejak awal komitmen dari para remaja masjid ini dan latar belakang aktivitas mereka ikut menjadi faktor pendukung. Kalaupun terdapat hambatan adalah masih minimnya ruang usulan dari 
remaja masjid kepada pengurus dalam konteks memberikan masukan tentang narasumber.

\section{Simpulan}

Berdasarkan hasil penelitian dan pembahasan peran dan inovasi remaja masjid dalam membuat program dakwah modern di Masjid Agung Jawa Tengah dalam konteks studi manajemen penyiaran Masjid Agung Jawa Tengah TV atau MAJT TV, dapat ditarik simpulan sebagai berikut. Bahwa partisipasi remaja masjid dalam proses pengembangan model dakwah modern di Masjid Agung Jawa Tengah sebagai bentuk inovasi mampu menujukkan hasil yang sangat positif. Sesuai dengan kompetensi yang dimiliki dalam bidang broadcasting menjadi jalan baru dalam pengembangan dakwah digital yang dilakukan oleh para ulama yang selama ini siar atau cara dakwah yang dilakukan masih cenderung terkesan konvensioanal.

Karakteristik dari model dakwah yang dilakukan dengan konsep mendokumentasian dalam bentuk audio visual, mengedit, dan mengunggahnya ke media social maupun konten program siaran dakwah di TVKU berhasil mendapat tempat di hati para penceramah dan juga masyarakat, sebab adanya inovasi ini mempermudah proses komunikasi antara ulama dengan masyarakat dalam konteks kemudahan akses, dan kualitas program dakwah yang lebih menarik karena ada sentuhan broadcast didalamnya.

Inovasi konten yang dilakukan masih terkendala komunikasi dengan kebijakan pengurus Masjid Agung Jawa Tengah terlebih dalam konteks siapa yang menjadi pengisi ceramah mengingat pihak masjid memberlakukan kebijakan ketat berkait persyaratan untuk bisa menjadi penceramah di Masjid Agung Jawa Tengah.

Proses komunikasi yang dilakukan oleh remaja masjid dengan para penceramah termasuk berbagai unit usaha dan pendukung yang ada di masjid menjadi proses bagian terpenting dari peroses pemberdayaan organisasi karena tanpa kerjasama dan komunikasi yang baik program Dakwah On TV ini mustahil bisa berjalan. Pada tingkatan partisipasi, hampir semuanya masuk kedalam tingkatan partisipasi dalam konteks memberikan informasi, konsultasi, pengambilan keputusan bersama, bertindak bersama dan memberikan dukungan. Konsistensi dan kontinuiti produksi kegiatan dakwah yang rutin dilakukan menjadi bukti tidak atau belum ditemukan faktor cukup berarti yang menjadi penghambat di kalangan remaja masjid di Masjid Agung Jawa dalam ikut berpartisipasi dalam membuat konten dakwah. Namun demikian para remaja ini perlu diberikan porsi atau ruang yang lebih luas dalam memberikan usulan kepada pengurus dalam konteks masukan tentang narasumber. Studi ini sangat penting karena masih minimnya penelitian yang mengupas tentang komunikasi dan pemberdayaan remaja masjid oleh pengurus masjid dalam bidang pengembangan model dakwah modern melalui kemitraan dakwah selama ini, sehingga diharapkan bisa menjadi referensi penelitian berikutnya terlebih di bidang komunikasi dan pemberdayaan. 
Daftar Pustaka

Artikel Jurnal:

Ilmu Dakwah: Academic Journal for Homiletic

Studies Volume 12 Nomor 1 (2018) 82-98 DOI: 10.15575/idajhs.v12i.2396 http://journal.uinsgd.ac.id/ind ex.php/idajhs ISSN 16930843 (Print) ISSN 2548-8708 (Online)

Haida, F. D. (2017). Difusi dan Adopsi Inovasi Cyber Village. Ilmu Sosial dan Politik.

Prihartono, Wahyu Anton, "Surat Kabar dan

Konvergensi Media Studi Deskriptif Kualitatif Model Konvergensi Media Pada Solopos" Jurnal Channel Vol. 4 No. 1 April 2016

Maguire, E. (2015). Self-Branding, Hotness, and

Girlhood in the Video Blogs of Jenna Marbles. Biography 38.1 Biographical Research Center, 72- 86.

Mansyur, Umar. 2016. Bahasa Indonesia dalam

Belitan Media Sosial: Dari Cabe-Cabean Hingga Tafsir Al-Maidah 51. In Prosiding Seminar Nasional \& Dialog Kebangsaan dalam Rangka Bulan Bahasa 2016 (pp. 145155). Fakultas Ilmu Budaya Universitas Hasanuddin. https://doi.org/10.312

27/osf.io/vpjh.

Mansyur, Umar. 2018. Belajar
Memahami

Bahasa Generasi Milenial. https://doi.org/10.31227/osf.i o/sxhp8

Buku:

Peter K Pringle, Michael F Star, William E

McCavit, Electronic Media management, Focal Press, Boston, 1991.Hal 2.

Morisan. 2005. Media Penyiaran Strategi

Mengelola Radio dan Televisi. Tangerang: Ramdina Prakarsa.

Sudibyo, Agus. 2004. Ekonomi Politik Media Penyiaran. LKIS. Yogyakarta.

Morisan. 2005. Media Penyiaran Strategi

Mengelola Radio dan Televisi. Tangerang: Ramdina Prakarsa

Morissan. (2008). Manajemen Media Penyiaran: Strategi Mengelola Radio dan Televisi. Jakarta: Kencana Prenada Media Group

Internet:

https://www.krjogja.com/beritalokal/jateng/semarang/terluas -di-asia-majt-butuhpengelolaan-profesional/

https://id.wikipedia.org/wiki/Masjid Agung_Ja wa_Tengah https://republika.co.id/berita/duniaislam/islamnusantara/17/01/09/ojhto5396 -majttv-segera-lakukan-uji-coba 